Journal of Economics and Policy
http://journal.unnes.ac.id/nju/index.php/jejak

\title{
FAKTOR - FAKTOR YANG MEMPENGARUHI PDRB KABUPATEN / KOTA JAWA TENGAH TAHUN 2008-2012
}

\author{
Yozi Aulia Rahman ${ }^{\bowtie}$, Ayunda Lintang Chamelia \\ Universitas Negeri Semarang, Indonesia \\ Permalink/DOI: http://dx.doi.org/10.15294/jejak.v8i1.3857
}

Received : 21 November 2014; Accepted: 15 Desember 2014; Published: March 2015

\begin{abstract}
High economic growth is the main condition for the continuation of regional economic development. To measure the progress of the regional economy, observation on the economyc growth rate in each area can be conducted. It is reflected in the increase of Gross Regional Domestic Product (GDP). The increase of GDP of regency/city in Central Java during the year of 2008- 2012 was influenced by several factors such as savings, credit, local generated revenue (PAD), and Expenditure. This study intends to analyze the affect of these factors to the level of GDP on districts / cities in Central Java during the years 2008-2012. The dependent variable used in this study is GDP. Meanwhile, the independent variables are savings, credit, revenue (PAD) and expenditure. This study uses multiple linear regression analysis by the OLS method using time series data in 2008 -2012 and data crosssection of 35 districts / cities in Central Java province which are often called as the data panel. The model is tested by using Fixed Effect. The result indicates that the results of the regression analysis on the $\alpha=5 \%$ shows that in partial, saving and loan have significant effect on GDP. Meanwhile, PAD variable and expenditurehave no significant effect on GDP districts / cities in Central Java province in 2008-2012.
\end{abstract}

Keywords: GDP of regency/city, Central Java, Saving, Credit, PAD, Local Expenditure

\begin{abstract}
Abstrak
Pertumbuhan ekonomi yang tinggi merupakan kondisi utama bagi kelangsungan pembangunan ekonomi daerah. Untuk mengukur kemajuan perekonomian daerah dengan mengamati seberapa besar laju pertumbuhan ekonomi yang dicapai daerah tersebut yang tercermin dari kenaikan Produk Domestik Regional Bruto (PDRB). PDRBKabupaten/Kota di Jawa Tengah selama tahun 2008 - 2012 mengalami pertumbuhan karena banyak yang mempengaruhinya, seperti: Tabungan, Kredit, PAD dan Belanja Daerah. Penelitian ini bertujuan untuk menganalisis seberapa besar faktor-faktor tersebut mempengaruhi tingkat PDRB kabupaten/Kota di Jawa Tengah selama tahun 2008-2012. Variabel dependen yang digunakan dalam penelitian ini adalah PDRB, sedangkan variabel-variabel independen yaitu Tabungan, Kredit, Pendapatan Asli Daerah (PAD) dan Belanja Daerah. Penelitian ini menggunakan analisis regresi linear berganda melalui metode OLS dengan menggunakan data time series 2008 -2012 dan data crosssection 35 kabupaten/kota di Provinsi Jawa Tengah atau yang dimaksud dengan data panel. Pengujian model dalam penelitian ini menggunakan metode FixedEffect. Hasil estimasi menunjukkan bahwa hasil analisis regresi pada $\alpha=5 \%$ menunjukkan bahwa secara parsial variabel tabungan dan kredit berpengaruh signifikan, sedangkan variabel PAD, dan Belanja Daerah tidak signifikan terhadap PDRB kabupaten/kota di Provinsi Jawa Tengah tahun 2008-2012.
\end{abstract}

Kata Kunci: PDRBKab/KotaDiJawaTengah,Tabungan,Kredit,PAD,Belanja Daerah

How to Cite: Rahman, Y. A., \& Chamelia, A. L. (2015). Faktor - Faktor Yang Mempengaruhi PDRB Kabupaten / Kota Jawa Tengah Tahun 2008-2012.. JEJAK Journal of Economics and Policy, 8 (1): 88-99

(C) 2015 Semarang State University. All rights reserved

\footnotetext{
Corresponding author :

Address: Kampus Unnes Sekaran, Semarang 50229

E-mail:yozzyaulia@gmail.com
}

ISSN 1979-715X 



\section{PENDAHULUAN}

Salah satu tujuan suatu negara adalah untuk meningkatkan pertumbuhan ekonominya. Salah satu ukuran pertumbuhan ekonomi adalah pendapatan nasional. Pendapatan nasional suatu negara dapat menunjukkan seberapa besar aktivitas perekonomian secara keseluruhan. Konsep pendapatan nasional adalah ukuran yang paling sering dipakai sebagai indikator pertumbuhan ekonomi namun bukan satusatunya indikator pertumbuhan ekonomi. Pertumbuhan ekonomi adalah sebuah proses, bukan merupakan suatu gambaran ekonomi pada suatu periode tertentu, ada perkembangan atau perubahan dan penggunaan waktu (Boediono, 1999).

Sementara itu pembangunan daerah merupakan pembangunan yang dimaksudkan untuk mendorong, memberdayakan masyarakat, menumbuhkan prakarsa serta meningkatkan partisipasi masyarakat dalam rangka membangun daerahnya, dan meningkatkan kesejahteraan masyarakat. Pembangunan yang dilaksanakan daerah meliputi berbagai bidang, salah satunya pembangunan ekonomi. Arsyad (1999) berpendapat bahwa pembangunan ekonomi daerah adalah suatu proses di mana pemerintah daerah dan masyarakat mengelola sumberdaya yang ada dan membentuk suatu pola kemitraan antara pemerintah daerah dengan sektor swasta untuk menciptakan lapangan kerja baru dan merangsang perkembangan kegiatan ekonomi (pertumbuhan ekonomi) dalam wilayah tersebut.

Sedangkan pembangunan ekonomi merupakan pembangunan yang pada hakekatnya bertujuan untuk meningkatkan kesejahteraan masyarakat. Dalam rangka meningkatkan kesejahteraan masyarakat maka diperlukan pertumbuhan ekonomi yang meningkat dan distribusi pendapatan yang lebih merata. Masalah pertumbuhan ekonomi di suatu daerah tergantung pada banyak faktor, salah satunya adalah kebijakan pemerintah itu sendiri. Kebijakan pemerintah tersebut harus dikenali dan diidentifikasi secara tepat supaya pertumbuhan ekonomi dapat tercapai di suatu daerah. Pertumbuhan ekonomi suatu daerah dapat diukur dengan melihat laju pertumbuhan PDRB atas dasar harga konstan.

Pembangunan ekonomi sebuah negara pada dasarnya bertujuan untuk mencapai kemakmuran masyarakat melalui pertumbuhan ekonomi yang tinggi. Pertumbuhan ekonomi merupakan pertumbuhan output yang dibentuk oleh berbagai sektor ekonomi sehingga dapat menggambarkan bagaimana kemajuan atau kemunduran yang telah dicapai oleh sektor ekonomi tersebut pada suatu periode waktu tertentu. Selain itu, pertumbuhan ekonomi juga menunjukkan sejauh mana aktivitas perekonomian akan menghasilkan tambahan pendapatan masyarakat pada suatu periode tertentu. Begitu juga pembangunan di daerah, sasaran utamanya adalah menciptakan pertumbuhan ekonomi dan pemerataan pembangunan, termasuk didalamnya pemerataan pendapatan antar daerah. Untuk mencapai sasaran pembangunan tersebut, diperlukan perencanaan pembangunan ekonomi yang baik.

Provinsi Jawa Tengah sebagai salah satu daerah otonom yang memiliki batas wilayah tertentu dengan jumlah penduduk terbesar ke dua di Pulau Jawa juga sedang mengalami suatu proses pembangunan ekonomi. Pembangunan di Provinsi Jawa Tengah yang 
berlangsung secara menyeluruh dan berkesinambungan telah meningkatkan perekonomian masyarakat. Pencapaian hasilhasil pembangunan di Provinsi Jawa Tengah tersebut sangat dipengaruhi oleh keberadaan kabupaten / kota yang berada pada wilayah provinsi tersebut termasuk sumberdaya yang dimilikinya. Pemerintah Provinsi Jawa Tengah sebagai pelaksana pembangunan di daerah Jawa Tengah juga dihadapkan pada permasalahan tentang bagaimana memacu pertumbuhan output daerahnya untuk meningkatkan kesejahteraan penduduknya.

Salah satu indikator yang penting untuk mengetahui kondisi ekonomi di suatu daerah atau provinsi dalam suatu periode tertentu ditunjukkan oleh data Produk Domestik Regional Bruto (PDRB). Nilai PDRB ini akan menjelaskan sejauh mana kemampuan daerah dalam mengelola atau memanfaatkan sumberdaya yang ada. Selain itu, kondisi perekonomian secara keseluruhan di setiap daerah juga dapat dilihat dari seberapa besar jumlah belanja daerah pada daerah bersangkutan. Pengeluaran pemerintah atau belanja daerah merupakan bentuk rangsangan yang dilakukan oleh pemerintah terhadap perekonomian daerah. Semakin besar nilai belanja daerah yang dialokasikan untuk pembangunan, maka akan meningkatkan kesejahteraan penduduk. Ini berarti kondisi ekonomi di daerah tersebut juga akan meningkat.

Pada kenyataannya, masih banyak ditemukan daerah yang mengalami kesulitan dalam melaksanakan pembangunan ekonominya setelah pelaksanaan otonomi daerah melalui Undang-Undang Nomor 33 Tahun 2004 mengenai pelimpahan wewenang dari pemerintah pusat kepada pemerintah daerah untuk merencanakan dan mengelola pembangunan daerahnya masingmasing berdasarkan potensi dan sumberdaya yang ada di wilayah yang bersangkutan. serta untuk mengatasi persoalan kemiskinan. Seperti yang dijelaskan pada Tabel 1 mengenai PDRB Kabupaten / Kota di Jawa Tengah atas dasar harga konstan tahun 2000 selama periode tahun 2008-2010 berikut.

Tabel 1. PDRB Kabupaten / Kota di Jawa Tengah atas dasar harga konstan tahun 2000 selama periode tahun 2008-2012

\begin{tabular}{|c|c|c|c|c|c|c|}
\hline \multirow{2}{*}{$\begin{array}{l}\mathrm{N} \\
\mathrm{O}\end{array}$} & \multirow[t]{2}{*}{ Kab/ Kota } & \multicolumn{5}{|c|}{ Tahun } \\
\hline & & 2008 & 2009 & 2010 & 2011 & 2012 \\
\hline 1 & Cilacap & $11.689 .092,9$ & $12.302 .859,95$ & $12.998 .128,8$ & $13 \cdot 749 \cdot 105,22$ & $14.517 .885,27$ \\
\hline 2 & Banyumas & $4.171 .468,95$ & $4.400 .542,23$ & $4.654 .634,02$ & $4 \cdot 927 \cdot 351,43$ & $5.221 .519,49$ \\
\hline 3 & Purbalingga & $2.257 \cdot 392,77$ & $2.390 .244,57$ & $2.525 .872,73$ & $2.679 .134,06$ & $2.845 .663,33$ \\
\hline 4 & Banjarnegara & $2.619 .989,61$ & $2.753 \cdot 935,73$ & $2.888 .524,12$ & $3.030 .587,58$ & $3.189 .651,65$ \\
\hline 5 & Kebumen & $2.721 .254,09$ & $2.872 .723,79$ & $3.016 .597,83$ & $3.168 .113,4$ & $3.238 .343,03$ \\
\hline 6 & Purworejo & $2.737 .087,13$ & $2.872 .723,79$ & $3.143 .097,82$ & $3.408 .112,6$ & $3 \cdot 327.675,4$ \\
\hline 7 & Wonosobo & $1.741 .148,31$ & $1.811 .092,67$ & $1.888 .808,28$ & $1.974 .114,16$ & $2.075 \cdot 562,03$ \\
\hline 8 & Magelang & $3 \cdot 761.388,59$ & $3.938 .764,68$ & $3.899 \cdot 372,86$ & $4.292 .354,46$ & $4 \cdot 542.888,65$ \\
\hline 9 & Boyolali & $3.899 \cdot 372,86$ & $4.100 .520,26$ & $4.248 .048,24$ & $4 \cdot 371.250$ & $4 \cdot 725 \cdot 556,65$ \\
\hline 10 & Klaten & $4.567 .200,96$ & $4 \cdot 761.018,67$ & $4.843 \cdot 247,28$ & 4.472 .217 & $5.211 .757,15$ \\
\hline 11 & Sukoharjo & $4 \cdot 540.75^{1,53}$ & $4 \cdot 756.902,5$ & $4.978 .263,31$ & $5.206 .687,7$ & $5.468 .708,95$ \\
\hline 12 & Wonogiri & $2.770 .435,78$ & $2.901 .577,44$ & $2.992 .794,29$ & $3 \cdot 134 \cdot 182,28$ & $3.325 .850,97$ \\
\hline
\end{tabular}




\begin{tabular}{|c|c|c|c|c|c|c|}
\hline 13 & Karanganyar & $4.900 .690,4$ & $5 \cdot 172.268,33$ & $5.452 .435,49$ & $5 \cdot 75^{2.064,99}$ & $6.086 .877,13$ \\
\hline 14 & Sragen & $2.729 \cdot 450,32$ & $2.893 \cdot 427,19$ & $3.068 .863,66$ & $3.270 .052,66$ & $3.485 .992,03$ \\
\hline 15 & Grobogan & $2.948 .793,8$ & $3.097 .093,25$ & $3.253 \cdot 398,56$ & $3 \cdot 370.343,7$ & $3 \cdot 578.062,78$ \\
\hline 16 & Blora & $1.913 .763,35$ & 2.010.908,67 & $2.115 \cdot 369,93$ & $2.170 .194,81$ & $2.278 .503,5$ \\
\hline 17 & Rembang & $2.093 .412,59$ & $2.186 .736,49$ & $2.283 .965,7$ & $2.384 .459,23$ & $2.500 .796,46$ \\
\hline 18 & Pati & $4.162 .082,37$ & $4 \cdot 357.144,03$ & $4 \cdot 579.852,54$ & $4.828 .723,12$ & $5.114 .682,32$ \\
\hline 19 & Kudus & $11.683 .819,7$ & $12.144 \cdot 95^{2,38}$ & $12.650 .309,16$ & 13.183.6o6,91 & $13 \cdot 754 \cdot 585,17$ \\
\hline 20 & Jepara & $3.889 .988,85$ & $4.085 \cdot 438,36$ & $4.270 .256,9$ & $4 \cdot 504 \cdot 551,89$ & $4.763 \cdot 305,8$ \\
\hline 21 & Demak & $2.787 \cdot 524,02$ & $2.901 .151,51$ & $3.020 .821,04$ & $3.156 .126,24$ & $3.302 .610,17$ \\
\hline 22 & Semarang & $5.079 .003,74$ & $5 \cdot 300.723,41$ & $5.560 .551,9$ & $5.877 .190,85$ & $6.223 .188,31$ \\
\hline 23 & Temanggung & $2.219 \cdot 155,63$ & $2.309 .841,53$ & $2.409 \cdot 386,4$ & $2.521 .439,02$ & $2.648 .488,46$ \\
\hline 24 & Kendal & $4.821 .181,52$ & $5.090 .286,6$ & $5 \cdot 392.965,71$ & $5 \cdot 717 \cdot 409,8$ & $6.033 .632,04$ \\
\hline 25 & Batang & $2.169 .854,55$ & $2.250 .616,82$ & $2.362 .482,41$ & $2.486 .765,6$ & $2.611 .528,72$ \\
\hline 26 & Pekalongan & $2.970 .214,98$ & $3.098 .071,49$ & $3.230 .351,23$ & $3 \cdot 384 \cdot 387,72$ & $3 \cdot 564.599,07$ \\
\hline 27 & Pemalang & $3.142 .808,7$ & $3.293 .056,25$ & $3 \cdot 455 \cdot 713,42$ & $3.622 .635,53$ & $3.813 .839,22$ \\
\hline 28 & Tegal & $3.286 .263,44$ & $3.460 .131,6$ & $3.627 \cdot 198,2$ & $3.801 .779,47$ & $4.001 .204,96$ \\
\hline 29 & Brebes & $4.998 .528,19$ & $5 \cdot 247 \cdot 897,41$ & $5 \cdot 507 \cdot 402,71$ & $5 \cdot 780.877,86$ & $6.082 .267,39$ \\
\hline 30 & $\begin{array}{l}\text { Kota } \\
\text { Magelang }\end{array}$ & $993.835,2$ & $1.044 .650,24$ & $1.108 .603,69$ & $1.169 \cdot 342,74$ & $1.245 .158,09$ \\
\hline 31 & $\begin{array}{l}\text { Kota } \\
\text { Surakarta }\end{array}$ & $4 \cdot 549 \cdot 342,95$ & $4.817 .877,63$ & $5.103 .886,25$ & $5.411 .912,32$ & $5.742 .861,31$ \\
\hline 32 & Kota Salatiga & $832.154,88$ & $869 \cdot 45^{2,99}$ & $913.020,04$ & $963.457,34$ & $1.016 .053,15$ \\
\hline 33 & $\begin{array}{l}\text { Kota } \\
\text { Semarang }\end{array}$ & $19.156 .814,3$ & $20.180 .577,9$ & $21.365 .817,8$ & $22.736 .136,19$ & $24 \cdot 196.487,78$ \\
\hline 34 & $\begin{array}{l}\text { Kota } \\
\text { Pekalongan }\end{array}$ & $1.887 .853,7$ & $1.978 .082,25$ & $2.087 .114,17$ & $2.200 .827,8$ & $2.324 .147,4$ \\
\hline 35 & Kota Tegal & $1.166 .587,87$ & $1.225 .102,11$ & $1.281 .528,2$ & $1.340 .227,74$ & $1.408 .144,1$ \\
\hline
\end{tabular}

Sumber : Badan Pusat Statistika Provinsi Jawa Tengah, 2013

Berdasarkan tabel 1 diatas, PDRB per kapita tertinggi selama 2008-2012 dimiliki oleh Kota Semarang dengan PDRB per kapita pada tahun 2008 sebesar Rp 19.156.814,3 dan pada tahun 2012 dengan PDRB per kapita sebesar Rp 24.196.487,78. Kemudian Kabupaten Cilacap pada tahun 2012 dengan PDRB sebesar Rp 14.517.885,27. Kabupaten Kudus pada tahun 2012 dengan PDRB sebesar Rp 13.754.585. Sedangkan PDRB per kapita terendah pada tahun 2012 dimiliki oleh Kota Salatiga sebesar Rp 1.016.053.
Perhitungan PDRB telah menjadi bagian yang sangat penting dalam makro ekonomi, khususnya tentang analisis perekonomian suatu wilayah. Hasil perhitungan PDRB ini memberikan kerangka dasar yang digunakan untuk mengukur aktivitas ekonomi yang terjadi dan berlangsung dalam suatu kegiatan perekonomian. Angka- angka PDRB tersebut sebagai indikator ekonomi makro dan juga sebagai landasan evaluasi kinerja perekonomian, dan penyusunan berbagai kebijakan. Indikator ekonomi ini juga 
memberikan gambaran aliran seluruh nilai tambah barang dan jasa yang dihasilkan dan seluruh faktor-faktor produksi yang digunakan oleh perekonomiaan untuk menghasilkan nilai tambah barang dan jasa.

Pengertian Produk Domestik Regional Bruto (PDRB) adalah jumlah nilai tambah yang dihasilkan untuk seluruh wilayah usaha dan jasa dalam suatu wilayah, menerapkan jumlah seluruh nilai barang dan jasa akhir yang dihasilkan seluruh unit ekonomi. PDRB dapat didefinisikan sebagai jumlah nilai tambah yang dihasilkan oleh seluruh unit usaha atau merupakan jumlah seluruh nilai barang dan jasa oleh seluruh unit ekonomi di suatu wilayah.

Nasution (2010) menyatakan bahwa faktor-faktor yang mempengaruhi pertumbuhan PDRB di Indonesia yaitu Pendapatan Asli Daerah (PAD), Dana Alokasi Umum (DAU), Dana Bagi Hasil (DBH), inflasi, Penanaman Modal Asing (PMA), Penanaman Modal Dalam Negeri (PMDN), Pengeluaran pemerintah daerah, dan tenaga kerja. Hasil penelitian menunjukkan bahwa inflasi, PMA dan PMDN tidak berpengaruh signifikan terhadap PDRB. Sedangkan, variabel PAD, DAU, DBH, Pengeluaran pemerintah daerah dan tenaga kerja berpengaruh signifikan terhadap PDRB.

Vidyattama (2010) melakukan penelitian mengenai mengenai faktor-faktor yang mempengaruhi pertumbuhan PDRB di Indonesia, antara lain investasi, modal manusia (human capital), populasi , belanja pemerintah daerah, infrastruktur dan perdagangan terbuka (openness trade). Hasil penelitian menunjukkan bahwa investasi dan populasi tidak berpengaruh signifikan terhadap pertumbuhan PDRB di Indonesia. Belanja pemerintah daerah berpengaruh positif terhadap pertumbuhan PDRB di Indonesia, sedangkan modal manusia, infrastruktur dan perdagangan terbuka berpengaruh positif terhadap pertumbuhan PDRB di Indonesia.

Dalam penelitian ini, faktor-faktor yang mempengaruhi Produk Domestik Regional Bruto (PDRB), yaitu Pendapatan Asli Daerah (PAD), kredit , tabungan dan belanja daerah.

Pendapatan Asli Daerah. Pembangunan ekonomi suatu daerah membutuhkan sejumlah dana yang diperoleh atau berasal dari berbagai sumber yang dikelola oleh daerah. Dalam otonomi daerah pembangunan ekonomi suatu daerah dilakukan berdasarkan kemampuan pendapatan daerah karena hak atas pengelolaan sumber-sumber keuangan daerah dan pembangunan ekonomi di daerah, telah diserahkan secara otonom kepada Pemerintah Daerah yaitu Pemerintah Kabupaten dan Kota.

Pendapatan Asli Daerah (PAD) adalah pendapatan yang diperoleh daerah, yang dipungut berdasarkan Peraturan Daerah sesuai dengan peraturan perundangundangan yang berlaku (Mulyanto, 2007). Selain itu, PAD juga dapat diartikan sebagai pendapatan yang bersumber dari pungutanpungutan yang dilakukan oleh pemerintah daerah berdasarkan peraturan-peraturan yang berlaku yang dapat dikenakan kepada setiap orang atau badan usaha, baik milik pemerintah atau swasta karena perolehan jasa yang diberikan pemerintah daerah tersebut, maka daerah dapat melaksanakan pungutan dalam bentuk penerimaan pajak, retribusi dan penerimaan lainnya yang sah diatur dalam undang-undang. Daerah yang pertumbuhan ekonominya positif mempunyai kemungkinan mendapatkan kenaikan PAD. Desentralisasi fiskal di negara-negara berkembang apabila tidak berpegang pada standar teori desentralisasi, hasilnya mungkin akan merugikan kondisi 
ekonomi dan efisiensi. Desentralisasi fiskal memungkinkan untuk melakukan korupsi pada level lokal / daerah. Oleh karena itu, peningkatan PAD akan dapat menurunkan pertumbuhan ekonomi (PDRB) di daerah tersebut.

Kredit. Menurut Undang-Undang Perbankan Nomor 10 Pasal 1 ayat 11 Tahun 1998, kredit adalah penyediaan uang atau tagihan yang dapat dipersamakan dengan itu, berdasarkan persetujuan atau kesepakata pinjam meminjam antara bank dengan pihak lain yang mewajibkan pihak peminjam melunasi utangnya setelah jangka waktu tertentu dengan pemberian bunga. Dalam artian luas kredit diartikan sebagai kepercayaan. Begitu pula dalam bahasa latin kredit berarti "credere" artinya percaya. Maksud dari percaya bagi si pemberi kredit adalah ia percaya kepada si penerima kredit bahwa kredit yang disalurkannya pasti akan dikembalikan sesuai perjanjian. Sedangkan bagi si penerima kredit merupakan penerimaan kepercayaan sehingga mempunyai kewajiban untuk membayar sesuai jangka waktu (Kasmir, 2002). Menurut Suyatno (1995), mengatakan bahwa kredit adalah hak untuk menerima pembayaran atau kewajiban untuk melakukan pembayaran pada waktu diminta, atau pada waktu yang akan datang, karena penyerahan barang-barang sekarang. Sebagai lembaga intermediasi, perbankan akan menyalurkan dana dalam bentuk kredit kepada masyarakat yang umumnya digunakan untuk membantu proses produksi output (modal usaha), investasi dan konsumsi.

Tang (2005) meneliti hubungan kausalitas antara kredit bank (bank lending) dengan pertumbuhan ekonomi di 5 negara pendiri ASEAN yaitu Malaysia, Singapura, Indonesia, Thailand dan Filipina. Ada dua uji kausiltas yang dalam penelitian tersebut, yaitu demand-following hypothesis (pertumbuhan ekonomi meningkatkan kredit bank) dan supply-leading hypothesis (kredit bank meningkatkan pertumbuhan ekonomi). Hasil penelitian menunjukkan bahwa supply-leading hypothesis terjadi di Thailand, demand-following hypothesis terjadi di Singapura. Sedangkan di Indonesia, Filipina dan Malaysia tidak menunjukkan terjadinya supply-leading hypothesis maupun demand-following hypothesis.

Tabungan. Menurut Undang-Undang Perbankan No. 10 Pasal 1 ayat 9 Tahun 1998, tabungan adalah simpanan yang penarikannya hanya dapat dilakukan menurut syarat tertentu yang disepakati, tetapi tidak dapat ditarik dengan cek, bilyet giro, dan / atau alat lainnya yang dipersamakan dengan itu. Selain itu, tabungan dapat didefinisikan sebagai simpanan dari pihak ketiga kepada bank yang penarikannya hanya dapat dilakukan menurut syarat-syarat tertentu. Tabungan merupakan salah satu jenis pembiayaan dalam negeri. Tabungan dihimpun dan diciptakan dengan cara menghemat atau menekan konsumsi, baik dari sektor pemerintah, swasta dan masyarakat. Teori Rostow menjelaskan bahwa salah satu cara untuk mempercepat kondisi / pertumbuhan ekonomi yang baik adalah dengan memperkuat tabungan nasional. Teori ini diperjelas lagi dengan teori Harrod-Domar yang menyebutkan bahwa semakin banyak porsi PDB / PDRB yang ditabung akan menambah capital stock sehingga meningkatkan perekonomian.

Dengan kata lain, jika tingkat tabungan tinggi, maka perekonomian akan mempunyai persediaan modal yang besar dan tingkat output yang tinggi, serta sebaliknya. Dasar 
dari model Solow inilah yang kemudian banyak dikaitkan dengan kebijakan fiskal. Defisit anggaran yang terus menerus dapat mengurangi tingkat tabungan nasional dan menyusutkan kemampuan berinvestasi. Konsekuensinya dalam jangka panjang, yakni rendahnya persediaan modal dan pendapatan nasional. Dalam Jangka panjang, persediaan modal domestik (The Domestic Capital Shock) harus dibiayai dengan tabungan domestik, selain itu Tabungan juga dapat digunakan untuk membayar utang (Freytag and Sebastian, 2013).

Belanja Daerah. Belanja daerah / pengeluaran pemerintah adalah nilai pembelanjaan yang dilakukan oleh pemerintah daerah yang digunakan terutama untuk kepentingan masyarakat. Menurut Undang-Undang No. 33 tahun 2004 Pasal 1 ayat 14 tentang Perimbangan Keuangan Antara Pemerintah Pusat dan Pemerintah Daerah, pengertian belanja daerah adalah kewajiban pemerintah daerah yang diakui sebagai pengurang nilai kekayaan bersih dalam periode tahun anggaran yang bersangkutan. Salah satu komponen dalam permintaan agregat (aggregate demand / AD) adalah pengeluaran pemerintah. Secara teori dinyatakan bahwa jika pengeluaran pemerintah meningkat, maka $\mathrm{AD}$ akan meningkat. Selain itu, peranan pengeluaran pemerintah di negara sedang berkembang sangat signifikan mengingat kemampuan sektor swasta dalam mendorong pertumbuhan ekonomi relatif terbatas sehingga peranan pemerintah sangat penting. Peningkatan AD berarti terjadi pertumbuhan ekonomi karena pertumbuhan ekonomi diukur dari Produk Domestik Regional Bruto (PDRB), maka peningkatan PDRB berarti peningkatan pendapatan.

Menurut Todaro dan Stephen (2004) bahwa ada tiga faktor atau komponen utama dalam pertumbuhan ekonomi dari setiap bangsa. Ketiga faktor tersebut adalah (1) akumulasi modal yang meliputi semua bentuk atau jenis investasi baru yang ditanamkan pada tanah, peralatan fisik, dan modal atau sumberdaya manusia; (2) pertumbuhan penduduk; dan (3) kemajuan teknologi. Dalam hal ini pengeluaran pemerintah berperan dalam pembentukan modal untuk membiayai pembangunan diberbagai bidang seperti sarana dan prasarana publik. Adanya berbagai fasilitas publik yang memadai, akan mendorong pertumbuhan ekonomi dan peningkatan pendapatan / kesejahteraan masyarakat.

Barro (1990) mengonstruksi model pertumbuhan endogen dimana memasukkan variabel belanja (pemerintah government public expenditure) dapat mempengaruhi pertumbuhan ekonomi. Menurut Chengliang dan Liutang (2009), model pertumbuhan endogen memprediksikan bahwa pengaruh kebijakan fiskal terhadap pertumbuhan ekonomi sangat bergantung kepada struktur belanja pemerintah dan perpajakan. Pajak merupakan salah satu sumber penerimaan negara yang digunakan untuk membiayai pembangunan, maka peningkatan pajak berarti peningkatan pengeluaran pemerintah. Keadaan ini membuat suatu siklus yang saling terkait dan saling mempengaruhi. Kenaikan pengeluaran pemerintah akan menyebabkan kenaikan pertumbuhan ekonomi (PDRB) dan kenaikan pertumbuhan ekonomi (PDRB) akan meningkatkan kemampuan keuangan pemerintah untuk membiayai pembangunan, baik di pusat maupun daerah.

Belanja pemerintah yang produktif (productive expenditure) dapat berpengaruh positif terhadap pertumbuhan, karena dapat meningkat produktivitas modal marjinal (Marginal of Productivity of Capital) dan 
produktivitas tenaga kerja marginal (Marginal of Productivity of Labor) (Chengliang dan Liutang, 2009). Pengeluaran pemerintah dapat meningkatkan produktvitas barang setengah jadi (intermediate goods). Barang setengah jadi diproduksi oleh tenaga kerja, modal publik dan swasta serta pelayanan publik. Peningkatan barang setengah jadi menyebabkan peningkatan jumlah barang jadi (final goods).

Guo dan Jia (2006) meneliti mengenai pengaruh belanja pemerintah terhadap pertumbuhan Ekonomi. Hasil penelitian tersebut menunjukkan bahwa belanja modal fisik (public physical capital) dan belanja modal manusia (public human capital) mempunyai pengaruh positif terhadap pertumbuhan Ekonomi dan koefisien untuk belanja modal fisik lebih besar daripada belanja modal manusia. Menurut Jin dan zhang (2011), Belanja pemerintah daerah yang produktif dapat meningkatkan rasio output terhadap modal (the ratio of output to capital), sedangkan belanja pemerintah yang tidak produktif dapat mengurangi rasio output terhadap modal.

\section{METODE PENELITIAN}

Data yang dipergunakan untuk mendukung penelitian ini adalah data sekunder. Data sekunder adalah data yang diperoleh melalui dokumen-dokumen resmi berupa data kabupaten/kota di Provinsi Jawa Tengah periode 2007. Data diperoleh dengan cara berikut. Pertama, studi kepustakaan dengan cara mempelajari berbagai literature serta tulisan-tulisan yang berhubungan dengan masalah yang diteliti. Kedua, studi dokumentasi untuk memperoleh data sekunder yang berhubungan dengan masalah penelitian diperoleh dari Badan Pusat
Statistik (BPS) Provinsi Jawa Tengah, data yang diperoleh yaitu PDRB Kabupaten / Kota di Provinsi Jawa Tengah periode 2008 - 2012, data - data Tabungan masing-masing kabupaten / kota di Provinsi Jawa Tengah, data Posisi Kredit kabupaten/kota di Provinsi Jawa Tengah, data Realisasi PAD kabupaten/kota di Provinsi Jawa Tengah dan data Realisasi Belanja Daerah kabupaten/kota di Provinsi Jawa Tengah.

Untuk dapat mengetahui pengaruh variabel independen terhadap variabel dependen digunakan analisis regresi Ordinary Least Square (OLS) terhadap model dengan kombinasi time series dan cross section, atau disebut juga data panel (pooled data). Terdapat beberapa keunggulan dari penggunaan data panel dibandingkan dengan data time series dan cross section. Pertama, dapat memberikan sejumlah data yang lebih besar, menaikkan derajat kebebasan, mengurangi kolinearitas diantara variabel penjelas, sehingga diperoleh estimasi ekonometrik yang efisien. Kedua, memberikan informasi yang penting bagi peneliti yang tidak dapat diberikan jika menggunakan data time series dan cross section.

Gujarati (2003) mengatakan bahwa terdapat beberapa keuntungan dari penggunaan model panel, seperti : (1) Mengingat penggunaan data panel juga meliputi data cross section dalam rentang waktu tertentu, maka data akan rentan dari heterogenitas. Penggunaan teknik dan estimasi data panel akan memperhitungkan secara eksplisit heterogenitas tersebut. (2) Dengan pengkombinasian, data akan memberikan informasi yang lebih, tingkat kolinearitas yang lebih kecil antar variabel dan lebih efisien. (3) Penggunaaan data panel, mampu meminimasi bias yang 
dihasilkan jika kita mengagregasikan data individu ke dalam agregasi yang luas.

Keuntungan lain dari penggunaan data panel adalah penyatuan informasi dari data cross section dan time series yang akan mengurangi permasalahan yang timbul akibat hilangnya variabel. Dalam data panel, hilangnya suatu variabel akan tetap menggambarkan perubahan lainnya akibat penggunaan data time series (Gujarati, 2003). Kesulitan utama model penelitian dengan panel data adalah faktor pengganggu akan berpotensi mengandung gangguan yang disebabkan karena penggunaan observasi time series dan cross section, serta gangguan yang disebabkan karena gabungan keduanya. Penggunan observasi cross section memiliki potensi terjadinya ketidakkonsistenannya parameter regresi karena skala data yang berbeda, sedangkan observasi dengan data time series menyebabkan terjadinya autokorelasi antar observasi. Dalam penelitian sering dihadapkan oleh kendala data, jika regresi diestimasi dengan data time series atau dengan data cross section, akan terjadi estimasi yang tidak efisien terutama disebabkan karena data yang terlalu sedikit. Salah satu metode yang digunakan untuk mendapatkan data yang efisien adalah data panel.

Winarno (2007) menjelaskan bahwa, dalam menganalisis data panel, teknik paling sederhana mengasumsikan data gabungan yang ada menunjukkan kondisi yang sesungguhnya. Hasil analisis regresi dianggap berlaku pada semua obyek pada semua waktu. Metode ini sering disebut dengan common effect. Kelemahan asumsi tersebut adalah ketidaksesuaian model dengan keadaan yang sesungguhnya.Kondisi tiap obyek saling berbeda, bahkan satu obyek pada suatu waktu akan sangat berbeda dengan kondisi obyek tersebut pada waktu yang lain. Oleh karena itu diperlukan suatu model yang menunjukkan perbedaan konstanta antar obyek, meskipun dengan koefisien regresor yang sama. Model tersebut dikenal dengan efek tetap (fixed effect), yaitu bahwa suatu obyek memiliki konstanta yang tetap besarnya untuk berbagai periode waktu. Demikian juga dengan koefisien regresinya, tetap besarnya dari waktu ke waktu (time invariant).

Analisis data dalam penelitian ini menggunakan teknik analisis data panel dengan menggunakan metode fixed effect. Pemilihan model dalam analisis ekonometrika merupakan langkah penting di samping pembentukan model teoritis dan model yang dapat ditaksir, estimasi pengujian hipotesis, peramalan, dan analisis mengenai implikasi kebijakan model tersebut. Penaksiran suatu model ekonomi diperlukan agar dapat mengetahui kondisi yang sesungguhnya dari sesuatu yang diamati.

Dengan variabel dependen PDRB dan variabel independen Tabungan, Kredit, PAD, dan

Belanja Daerah diperoleh model regresi sebagai berikut :

$\operatorname{PDRB}=\beta_{\mathrm{o}}+\beta_{1} T A B_{\mathrm{it}}+\beta_{2} C R E_{\mathrm{it}}+\beta_{3} P A D_{\mathrm{it}}+$ $\beta_{4} E X P_{\text {it }}+\mu$

dimana $:$ PDRB = PDRB Kab/Kota Di Provinsi Jawa Tengah Tahun, $\mathrm{TAB}=$ Tabungan Kab/Kota di Provinsi Jawa Tengah, $\mathrm{CRE}=$ Posisi Kredit Kab/Kota di Provinsi Jawa Tengah PAD = Realisasi PAD Kab/Kota di Provinsi Jawa Tengah, EXP = Realisasi Belanja Daerah di Jawa Tengah.

\section{HASIL DAN PEMBAHASAN}

Setelah dilakukan beberapa pengujian ternyata teknik yang paling tepat digunakan 
untuk mengestimasi model regresi tersebut yaitu model Fixed Effect. Adapun hasil regresi dari model Fixed Effect sebagai berikut.

$\mathrm{PDRB}=34023260 \beta_{\mathrm{o}}+, 242093 T A B_{\text {it }}+\mathrm{o}$, $154483 C R E_{\text {it }}+0,000476 P A D$ it $+6,78 E X P_{\text {it }}$ ...(2)

Model regresi yang ditemukan diperoleh Adjusted $\mathrm{R}^{2}$ sebesar $=0,9965$ artinya bahwa sebesar 99,65\% variabel PDRB per kapita dapat dijelaskan oleh variabel Tabungan, Kredit, PAD dan belanja publik dan sisanya $0,35 \%$ dijelaskan oleh variabel lain diluar model. Pengaruh tersebut signifikan pada 0,05 karena hasil pengujian ditemukan nilai $F$ hitung sebesar 1020,726. Dengan demikian dapat disimpulkan bahwa secara simultan Tabungan, Kredit, PAD dan belanja publik berpengaruh terhadap PDRB di Jawa Tengah.

Penelitian lebih lanjut ditemukan bahwa Tabungan berpengaruh positif dan signifikan terhadap PDRB di Jawa Tengah. Variabel Tabungan dengan koefisien sebesar o,242093. Hal ini tentu saja sesuai dengan teori menurut Solow, tingkat tabungan yang lebih tinggi hanya akan mesningkatkan pertumbuhan untuk sementara waktu sampai perekonomian mencapai kondisi steady-state baru yang lebih tinggi dari sebelumnya. Tabungan akan meningkatkan ketersediaan dana untuk melakukan investasi. Tentunya yang diharapkan terjadinya peningkatan investasi belanja modal termasuk untuk pembangunan infrastruktur berupa jalan nasional / kabupaten, jalan tol, jembatan, irigasi , bendungan, dan penyediaan fasilitas lainnya. Banyaknya tabungan juga dapat digunakan untuk membayar hutang yang dilakukan pemerintah.
Selain itu variabel Kredit berpengaruh positif dan signifikan terhadap PDRB di Jawa Tengah dengan koefisien o,154483. Hal ini tentu saja sesuai dengan teori bahwa Semakin besar nilai kredit yang disalurkan kepada masyarakat, maka semakin meningkat nilai pertumbuhan ekonomi (PDRB) di daerah tersebut karena proses produksi barang dan jasa yang baik dan lancar akan mengakibatkan tingkat kesejahteraan penduduknya merata.

Berbeda dengan hasil Realisasi PAD dan Realisasi Belanja Daerah yang memiliki hubungan positif namun tidak signifikan terhadap PDRB Jawa Tengah dengan koefisien sebesar 0,000476. Hasil penelitian ini berlawanan dengan penelitian Nasution (2010) yang menemukan bahwa PAD berpengaruh positif terhadap pertumbuhan. Desentralisasi fiskal memungkinkan para pemimpin daerah untuk melakukan korupsi pada level lokal / daerah. Oleh karena itu, peningkatan PAD akan dapat menurunkan pertumbuhan ekonomi (PDRB) di daerah tersebut. Selain itu, penerimaan daerah dari PAD tidak begitu optimal karena penerimaan pajak dan retribusi daerah tidak maksimal dikumpulkan oleh pemerintah daerah. Masalah lain adalah terjadinya ketimpangan penerimaan PAD antar kabupaten/ kota di Jawa Tengah, terdapat daerah yang memiliki penerimaan PAD sangat tinggi namun juga terdapat daerah yang memiliki penerimaan PAD yang rendah.

Hasil dari Realisasi Belanja daerah memiliki koefisien terbesar jika dibandingkan oleh variabel independen lain yaitu sebesar 6,78 memiliki hubungan positif namun tidak signifikan terhadap PDRB Kab/Kota di Jawa Tengah. Hasil tersebut menunjukan sesuai teori peningkatan belanja daerah/ pengeluaran 
pemerintah akan meningkatkan $\mathrm{AD}$ berarti terjadi pertumbuhan ekonomi karena pertumbuhan ekonomi diukur dari Produk Domestik Regional Bruto (PDRB), maka peningkatan PDRB berarti peningkatan pendapatan. Pengaruh tidak signifikannya antara Realisasi Belanja Daerah terhadap PDRB Kab/Kota di Jawa Tengah diharapkan peranan Pemerintah dalam mengelola pengeluaran pemerintah untuk menyediakan infrastruktur bagi setor swasta mengingat kemampuan sektor swasta dalam mendorong pertumbuhan ekonomi relatif terbatas sehingga peranan pemerintah sangat penting. Hasil penelitian ini berlawanan dengan penelitian yang dilakukan oleh Guo dan Jia (2006) yang menemukan bahwa belanja modal fisik (public physical capital) dan belanja modal manusia (public human capital) mempunyai pengaruh positif terhadap pertumbuhan Ekonomi dan koefisien untuk belanja modal fisik lebih besar daripada belanja modal manusia. Hasil penelitian ini juga berlawanan dengan penelitian yang dilakukan Nasution (2010) yang menyatakan pengeluaran pemerintah berpengaruh terhadap pertumbuhan.

Terdapat beberapa alasan yang memungkinkan menyebabkan variabel belanja daerah tidak berpengaruh terhadap PDRB, (1) penyerapan anggaran terutama belanja fisik tidak maksimal dan lebih banyak dilakukan pelaksanaan program pada semester II , (2) maraknya praktek korupsi yang dilakukan oleh beberapa oknum pejabat daerah yang sangat menghambat pelaksanaan pembangunan di daerah , (3) porsi belanja non fisik, seperti belanja pegawai melebihi porsi anggaran belanja fisik , apalagi jika aparatur daerah bekerja tidak maksimal dan kurang produktif , (4) ketimpangan dalam penerimaan Dana Bagi Hasil Sumber Daya Alam (DBHSDA), daerah yang memiliki sumber daya alam yang melimpah akan menerima DBHSDA yang tinggi, sedangkan daerah yang tidak memiliki sumber daya alam yang melimpah akan menerima DBHSDA yang rendah.

\section{KESIMPULAN}

Pertumbuhan PDRB Provinsi Jawa Tengah yang meningkat hendaknya lebih didukung denagan peningkatan Tabungan, Posisi kredit, Realisasi Pendapatan Asli Daerah dan Realisasi Belanja Daerah karena ke empat variabel tersebut berhungan positif terhadap PDRB Kabupaten

/ Kota di Jawa Tengah. Berdasarkan simpulan maka diperoleh implikasi kebijakan bahwa terkait dengan belanja daerah, pemerintah daerah harus konsisten merealisasikan anggaran yang berorientasi pada peningkatan pelayanan publik sehingga tingkat kesejahteraan masyarakat dapat meningkat dan secara agregat dapat meningkatkan PDRB Kabupaten / Kota di Jawa Tengah.

\section{DAFTAR PUSTAKA}

Arsyad, Lincoln. (1999). Pengantar Perencanaan dan Pembangunan Ekonomi Daerah. Yogyakarta: Badan Penerbit Fakultas Ekonomi.

Badan Pusat Statistik. (2009). Jawa Tengah Dalam Angka 2009. Jawa Tengah: BPS

Badan Pusat Statistik. (2010). Jawa Tengah Dalam Angka 2010. Jawa Tengah: BPS

Badan Pusat Statistik. (2011). Jawa Tengah Dalam Angka 2011. Jawa Tengah: BPS

Badan Pusat Statistik. (2012). Jawa Tengah Dalam Angka 2012. Jawa Tengah: BPS

Badan Pusat Statistik. (2013). Jawa Tengah Dalam Angka 2013. Jawa Tengah: BPS

Barro, R.J. (1990). Government Spending in a Simple Model of Endogenous Growth. Journal of Political Economy Vol 98 pp 103-125.

Boediono. (1999).Teori Pertumbuhan Ekonomi. Yogyakarta: BPFE.

Chengliang, Yan., and Gong Liutang. (2009). Government Expenditure, Taxation and Long- 
Run Growth. Frontiers of Economics in China Vol 4(4) pp 505-525.

Freytag, Andreas., and Sebastian Voll. (2013). Institutions and Savings in Developing and Emerging Economies. Public Choice Vol 157 pp 475-509.

Gujarati, Damodar N. (2003) Basic Econometrics, Fourth Edition. New York: McGraw Hill

Guo, Qingwang., and Jia Junxue. (2006). The Effects of Government Public Capital Investment on Economic Growth. Economics Research (7) pp 29-40.

Jin, Tao., and Jianzhui Xhang. (2011). Effect of Local Government Expenditure on the Ratio of Output to Capital: Evidence from Panel Data at China's Provincial Level. Frontiers of Economics in China Vol 6 (2) pp 249-270

Kasmir. (2002). Bank dan Lembaga Keuangan Lainnya. Edisi Revisi 2002. Jakarta: PT. Raja Grafindo Persada.

Kusumaningsih, Widya. (2012). Analisis Faktor - Faktor Yang Mempengaruhi Kondisi Pdrb Kabupaten / Kota Di Provinsi Jawa Tengah Tahun 2009. Surakarta:Universitas Sebelas Maret.

Mulyanto. (2007). Aspek dan Dimensi Keuangan Daerah di Era Otonomi dan Desentralisasi. Universitas Sebelas Maret Surakarta.

Nasution, Hendry Sulaiman. (2010). Analisis Faktor Faktor yang Mempengaruhi Pertumbuhan Produk Domestik Regional Bruto era Desentralisasi Fiskal di Propinsi Banten Periode 2001:1-2009:4. Media Ekonomi Vol 18 No 2 Agustus.
Prabowoningtyas, Dwi Handini. (2011). Analisis FaktorFaktor Yang Mempengaruhioutput Daerah Kabupaten/Kota Di Provinsi Jawa Tengah Menggunakan Model Pertumbuhan Neo - Klasik (Analisis Data Panel Tahun 2007-2008). Semarang: Universitas Diponegoro.

Sukirno, Sadono. (200o). Pengantar Teori Ekonomi. Jakarta: PT. Raja Grafindo Persada

Suryono, Bagus Wiratno. (2010). Analisis Pengaruh Pendapatan Asli Daerah, Tingkat Investasi Dan Tenaga Kerja Terhadap PDRB Jawa Tengah. Semarang: Universitas Diponegoro.

Suyatno. (1995). Dasar-dasar Perkreditan. Gramedia Pustaka Utama : Jakarta

Tang, Cheong Tuck. (2005). An Examination Of The Causal Relationship Between Bank Lending And Economic Growth: Evidence From Asean. Savings and Development, Vol. 29, No. 3 (2005), pp. 313-343

Todaro, Michael P., dan Stephen C. Smith. (2004). Pembangunan Ekonomi di Dunia Ketiga Jilid 1 edisi 8. Jakarta: Penerbit Erlangga.

Undang-Undang Nomor 10 Tahun 1998 tentang Perbankan.Jakarta

Undang-Undang Nomor 33 Tahun 2004 tentang Pemerintahan Daerah.Jakarta

Vidyattama, Yogi. (2010). A Search for Indonesia's Regional Growth Determinants. ASEAN Economic Bulletin, Vol. 27, No. 3 Desember pp. 281-294

Winarno, Wing Wahyu. (2007). Analisis Ekonometrika dan Statistika dengan Eviews. Yogyakarta: UPPSTIM YKPN 